\title{
Diversification In An Emerging Market: A Closer Look At The Indian Stock Market
}

Jayen B. Patel, (Email: JPatel@adelphi.ede), Adelphi University

\begin{abstract}
We find that the Indian stock market generated returns comparable to those of the U.S. stock market during the period January 1991 to July 2005. We also find that the Indian stock market produced returns substantially higher than U.S. equity returns during various sub-periods when the U.S. market declined. We demonstrate that the Indian stock market presents important return and diversification benefits to U.S. investors.
\end{abstract}

\section{INTRODUCTION}

$\varnothing^{2}$

n the early 1990's, the Indian government instituted a number of policy changes designed to encourage foreign financial institutions to invest in the Indian equity markets; for example, as reported by Echeverri-Gent (2004), the world's first satellite trading system was introduced in India. With the satellite system, trading that had previously been restricted to the exchange floor was replaced by electronic systems linking traders throughout the country. Further, according to Echeverri-Gent, the satellite system led to the result that India's two largest stock exchanges generated, respectively, the third and sixth largest trading volume in the world by the year 2003. Additionally, since the early 1990's, the Indian economy has become increasingly more integrated with the world economy.

The Bombay Stock Exchange (BSE) opened in 1875 and is generally regarded as the oldest stock exchange in Asia (BSE Website, September 1, 2005). However, it was not until the early 1990's that the BSE initiated substantive policy changes in order to make equity trading more transparent. The response to these policy changes from multinational corporations and the international investment community was overwhelming. Until the early 1990 's, there was virtually no equity research done in India; by 2004, most leading U.S. financial institutions were outsourcing equity research to India. (Echeverri-Gent, 2004).

Recent World Bank data indicates that India has joined the league of the world's ten largest economies, as measured by 2004 gross domestic product (GDP) (World Bank, July 15, 2005). Additionally, another World Bank study reports that remittances (i.e., money sent home by immigrant workers employed abroad) to India have grown dramatically in recent years. Remittances are the largest source of external finance after foreign direct investment (FDI) and, in some cases, remittances to developing countries exceed FDI. India is the world's largest recipient of remittance flows. Money sent home to India by non-resident Indians has risen from an average of approximately two billion U.S. dollars per year in the late 1980's to seventeen billion U.S. dollars in 2003. For 2003, the largest remittance flows to all receiving countries came from the U.S. (\$34.1 billion).

Recent economic reforms and liberalization policies introduced by the Indian government make the Indian stock market attractive to U.S. investors. Emerging stock markets are appealing to U.S. investors for two significant reasons. First, they offer the potential for high returns, and second, the emerging stock markets offer greater diversification benefits than do developed countries. However, some recent studies report that the correlation between stock market returns in emerging markets and returns in the developed markets is steadily increasing. Evidence is mixed regarding whether emerging markets offer diversification benefits to U.S. investors.

Patel (2003) examined the relationship between ten emerging stock markets of Asia (including India) and the U.S. stock market. He reports that the correlation between returns in the emerging markets of Asia and U.S. stock 
market returns has increased in recent years. However, the stock markets of three South Asian countries (i.e., India, Pakistan and Sri Lanka) continue to present risk reduction opportunities to U.S. investors.

We re-examine and extend Patel's study, comparing the Indian stock market with the U.S. stock market for the period January 1991 to July 2005. We employ major indexes of the Indian and U.S. stock markets and we find that the Indian stock market presents substantial diversification benefits to U.S. investors. The results are more impressive during the recent period when the U.S. stock market generated substantially lower returns. We conclude that it is in fact advantageous for U.S. investors to diversify by investing in the Indian market, particularly during periods of lower returns in the U.S. market.

\section{LITERATURE REVIEW}

Chatrath, Ramchander and Song (1996) examined the relationship between the Indian stock market and the stock markets of the U.S. and other developed countries using daily data for the period 1984 to 1992 . They used the Bombay Stock Exchange National Index (BSENI) and the Dow Jones Industrial Average (DJIA) as representative indexes for the Indian and U.S. markets, respectively. The authors identify two major concerns in portfolio diversification studies. First, return comparisons between countries are exposed to currency risk. Second, correlations between stock returns for various countries must be stable over time in order to be able to employ past correlations as a proxy in creating optimal portfolios. They find that the Indian stock market had low correlations with the markets of the developed countries. Therefore, the Indian market offered diversification benefits for investors in the developed countries for the period 1984 to 1992.

Barry, Peavy III and Rodriguez (1998) examined the return characteristics of emerging stock markets along with returns to several U.S. market indexes. They conclude that investments in emerging markets increased in importance because many investors from developed nations believe that markets in the developing countries have the potential for high returns along with increased diversification benefits. The authors find that the emerging markets do not consistently generate high returns. However, these markets continue to provide diversification benefits for investors from the developed countries. The authors find that the relative ranking of returns between developed and emerging stock markets largely depends on the time period. Therefore, optimal asset allocation between developed and emerging markets changes over time.

Arshanapalli and Kulkarni (2001) examined the relationship between the U.S. and the Indian stock markets. They explain that this relationship is important because of the transformation of the Indian economy to a more open economy over the decade of the nineties. The authors state that increased integration with developed nations is beneficial to India's economic prosperity, but greater integration with the world economy also makes the Indian economy more vulnerable to outside risk. The authors collected daily data for one Indian index (the BSE 30 Index) and two U.S. indexes (the NASDAQ composite and the NYSE composite) for the period January 1991 to December 1999. They expected the Indian stock index to be more integrated with NASDAQ than with the NYSE composite because the majority of the Indian companies listed in the U.S. over that time period were in the NASDAQ index. Most of these companies became listed by NASDAQ during 1998 and 1999. In order to test the hypothesis, the authors divided their data into two sub-periods, pre-1998 and 1998-99. They found that the NASDAQ index was more highly correlated with the Indian stock market than was the NYSE index. Furthermore, the correlation increased from the first sub-period (pre-1998) of their study to the second sub-period (1998-99).

Patel (2003) examined the relationship between the U.S. stock market and ten emerging markets of Asia. He utilized Morgan Stanley Country Indexes as representative stock market indexes during the period January 1993 to December 2001. Patel analyzed two sub-periods defined by the 1997 Asian financial crisis: January 1991 to June 1997, and July 1997 to December 2001. The second sub-period generated generally lower returns in comparison to the first for stock markets of almost all countries, including the U.S. The correlation coefficients of stock market returns for the ten Asian emerging markets increased with those of the U.S. market during the second sub-period. Patel concluded that, in recent years, the emerging markets have become more integrated with the U.S. stock market. $\mathrm{He}$ also found that the correlations of returns between the U.S. market and the South Asian stock markets of India, Pakistan and Sri Lanka continued to remain low during the second sub-period in comparison with the correlations for 
the other emerging markets of Asia. The Indian stock market is considerably larger than the other two South Asian markets. Patel suggests the need for researchers to further examine the Indian stock market to determine whether it continues to provide investment opportunities and diversification benefits to U.S. investors.

\section{DATA}

In this study, we use data from the Bombay Stock Exchange (BSE) to represent the Indian stock market. In 1956, the BSE was the first stock exchange to receive permanent recognition from the government of India (BSE Website, September 1, 2005). The BSE is professionally managed by its board of directors, consisting of a managing director, representatives of BSE trading members, and other market experts. Daily operations of the exchange are led by the managing director and a number of professionals. Exchange procedures are designed to enhance transparency and to safeguard market integrity (BSE Website, September 1, 2005).

We utilize three major Indian market indexes, namely, the BSE 30 stock index (BSE 30), the BSE 100 stock index (BSE 100) and the BSE 200 stock index (BSE 200). The BSE 30 index is popularly known as the SENSEX because it viewed as the pulse and barometer of the overall Indian stock market. The BSE 30 was created in 1986, with a base year of 1978-79. The index is comprised of thirty of the largest Indian companies whose stocks are actively traded and are highly liquid. The methodology used to construct and maintain the index is based on globally accepted standards (BSE Website, September 1, 2005). The BSE 30 index is widely reported internationally as a representative Indian stock market index.

The BSE 100 index was created on January 3, 1989, with 1983-84 as the base year, in order to satisfy the need for an index that includes more stocks than the thirty in the popular BSE 30 index. The exchange created the BSE 100 in order to provide a more representative, broad-based index. The BSE 100 consists of one hundred stocks, and is referred as the "BSE National Index." Selection of a company for inclusion in the index is based primarily on market activity, although consideration is also given to the objective of including representation of as many industries as possible in the index.

The BSE experienced a tremendous surge in registration and listing of companies during the 1990's. There were 992 companies listed in 1984; the total increased to 3200 companies by early 1994. During the same period, combined market capitalization of the exchange increased exponentially. In response, the exchange created a new broad-based index, the BSE 200, on May 27, 1994, using a base period of 1989-90. The primary criteria for selection of stocks for the index were market capitalization and trading volume, in addition to some other fundamental characteristics of the listed companies.

Data for the three indexes are available, beginning with January 1991, from the Bombay Stock Exchange Website. We have collected index values for the last trading day of each month for the three major indexes for the period January 1991 to July 2005. We have, therefore, 175 index value observations for each of the three Indian stock indexes. Naturally, Indian stock indexes are reported in the local currency, Indian rupees. We also collected exchange rates for Indian rupees with the U.S. dollar from the Federal Reserve Website. We converted each Indian index value observation from rupees to dollars using the exchange rate in effect on each observation date. Monthly returns were then calculated using the standard methodology. We have, therefore, 175 monthly return observations for each of the three Indian stock indexes for the period January 1991 to July 2005, in U.S. dollars.

We want to compare the relationship of the Indian stock market with the U.S. stock market so that we can determine whether there is any benefit to U.S. investors from investing, and diversifying, in the Indian stock market. Major U.S. stock indexes reported in the popular print and electronic media are the Dow Jones Industrial Average (DJIA), the NASDAQ composite stock index (NASDAQ) and the S\&P 500 stock index. We utilized these three indexes as representative of the major U.S. stock markets. We collected index values for the last trading day of each month for each of the three U.S. indexes from the Yahoo Website. Returns were calculated using the standard methodology. Therefore, we have monthly return observations for each of the three major U.S. stock indexes and three major Indian stock indexes for the period January 1991 to July 2005. We have 175 monthly return observations, measured in U.S. dollars, for each of the six indexes. 


\section{COMPARATIVE PERFORMANCE OF MAJOR U.S. AND INDIAN STOCK INDEXES}

We compute the mean and standard deviation of returns for each of the six stock indexes for the overall period, January 1991 through July 2005; the results are presented in Table 1. We find that the three U.S. stock indexes generated relatively high returns for the overall period. The reader may remember that the U.S. stock market produced extremely high returns during much of the nineties. Of the three U.S. stock indexes, the NASDAQ generated the highest mean monthly return $(1.28 \%)$ and also had the highest volatility (7.32\%). The DJIA (0.89\%) and S\&P $500(0.84 \%)$ had comparatively lower returns than the NASDAQ, but also had lower standard deviations (4.16\% and $4.08 \%$, respectively).

Remarkably, during this period, the Indian stock market generated returns comparable to those of the U.S. stock market. Each of the three Indian stock indexes, the BSE 30 (1.03\%), the BSE $100(1.09 \%)$ and the BSE 200 $(1.13 \%)$ had higher returns than the DJIA and the S\&P 500. The returns of the three Indian stock indexes are comparable to, but somewhat lower than, those for NASDAQ.

\begin{tabular}{|cccc|}
\hline \multicolumn{4}{|c|}{ Table 1 } \\
\hline \multicolumn{4}{|c|}{$\begin{array}{c}\text { Monthly Return Characteristics Of Major U.S. And Indian Stock Market Indexes } \\
\text { January 1991 To July 2005 }\end{array}$} \\
\hline Index & Mean & Standard Deviation & Number of Observations \\
\hline DJIA & 0.89 & 4.16 & 175 \\
NASDAQ & 1.28 & 7.32 & 175 \\
S\&P 500 & 0.84 & 4.08 & 175 \\
BSE 30 & 1.03 & 8.80 & 175 \\
BSE 100 & 1.09 & 9.21 & 175 \\
BSE 200 & 1.13 & 9.90 & 175 \\
\hline
\end{tabular}

In Table 2, we report results of statistical tests of pairwise comparisons between each U.S. stock index and the other five stock indexes (i.e., with each of the other two U.S. indexes and each of the three Indian indexes). Analysis using t-tests (parametric) as well as Wilcoxon (non-parametric) statistics indicates that none of the indexes is statistically significantly different from any other index. Therefore, we can affirmatively conclude that the Indian stock market generated returns comparable to those of the U.S. stock market for the overall period of the study, a period that includes the unprecedented U.S. market returns of the 1990's.

\begin{tabular}{|cccc|}
\hline \multicolumn{4}{c|}{ Table 2 } \\
\hline \multicolumn{4}{|c|}{ Significance Test Results Of Comparisons Of Each U.S. Stock Index With Other Stock Indexes } \\
& \multicolumn{2}{|c|}{ January 1991 To July 2005 } \\
\hline Index Comparisons & T-statistics Significance & DF & Wilcoxon Significance \\
\hline DJIA - NASDAQ & 0.35 & 174 & 0.22 \\
DJIA - S\&P 500 & 0.69 & 174 & 0.79 \\
DJIA - BSE 30 & 0.84 & 174 & 0.73 \\
DJIA - BSE 100 & 0.78 & 174 & 0.68 \\
DJIA - BSE 200 & 0.76 & 174 & 0.66 \\
NASDAQ - S\&P 500 & 0.22 & 174 & 0.14 \\
NASDAQ - BSE 30 & 0.73 & 174 & 0.60 \\
NASDAQ - BSE 100 & 0.79 & 174 & 0.55 \\
NASDAQ - BSE 200 & 0.85 & 174 & 0.59 \\
S\&P 500 - BSE 30 & 0.78 & 174 & 0.73 \\
S\&P 500 - BSE 100 & 0.73 & 174 & 0.68 \\
S\&P 500 - BSE 200 & 0.71 & 174 & 0.69 \\
\hline
\end{tabular}


In the earlier study, Patel (2003) compared the performance of the U.S. stock market with the ten emerging markets of Asia for the period January 1993 to December 2001 using Morgan Stanley Country Indexes. He documented that the U.S. stock market generated higher returns and lower risks than almost all of the ten emerging markets. The relatively high returns of both the Indian and U.S. stock markets, as demonstrated in this study, therefore appears to represent promising results for U.S. investors in terms of opportunities for diversification.

However, many prior studies have documented the fact that correlations among national stock indexes have increased over time, along with increased globalization and world trade. In fact, some studies report increases in the correlation of the U.S. market with foreign markets during domestic stock market declines, resulting in decreased benefits from international diversification. Patel (2003) demonstrated that the South Asian markets, including, predominantly, India (along with Pakistan and Sri Lanka), continue to have lower correlations with the U.S. markets when compared to the correlations between the U.S. and other emerging markets of Asia. He suggested further examination of the Indian market. We intend to reexamine and extend Patel's (2003) study by focusing exclusively on the relationship between the U.S. and the Indian stock markets. We report our results in subsequent sections.

\section{DIVERSIFICATION POTENTIAL OF INDIAN STOCK MARKET}

We calculate correlation coefficients for each U.S. index with each of the other five stock indexes over two sub-periods. Our dividing point is defined by the Asian financial crisis (see Patel (2003)). However, here we use different indexes, and also extend our data to July 2005. Patel (2003) examined stock market performance of ten emerging markets of Asia with the U.S. stock market. He utilized one Morgan Stanley Country Index (MSCI) for each country. In this study, we compare the relationship and performance of the U.S. stock market with the Indian stock market. We utilize three major indexes of the U.S. stock market as well as three major indexes of the Indian stock market. Additionally, our first sub-period begins in January 1991, whereas Patel's (2003) first sub-period begins in January 1993 and ends in June 1997. Finally, our second sub-period extends the end of our study from December 2001 to July 2005. Our findings for these comparisons are reported in Table 3.

\begin{tabular}{|c|c|c|c|c|c|c|}
\hline \multicolumn{7}{|c|}{ Table 3} \\
\hline \multicolumn{7}{|c|}{$\begin{array}{c}\text { Correlations Of Each U.S. Stock Index With The Other Stock Indexes } \\
\text { Two Sub-Periods }\end{array}$} \\
\hline Index & DJIA & NASDAQ & S\&P 500 & BSE 30 & BSE 100 & BSE 200 \\
\hline \multicolumn{7}{|c|}{$\begin{array}{l}\text { Panel A: Sub-period } 1 \\
\text { (Jan. } 91 \text { to Jun. 97) }\end{array}$} \\
\hline DJIA & 1 & $0.66^{* *}$ & $0.93 * *$ & 0.03 & -0.01 & 0.01 \\
\hline NASDAQ & $0.66^{* *}$ & 1 & $0.76^{* *}$ & 0.08 & 0.05 & 0.05 \\
\hline S\&P 500 & $0.93 * *$ & $0.76^{* *}$ & 1 & 0.01 & -0.04 & -0.02 \\
\hline \multicolumn{7}{|c|}{$\begin{array}{l}\text { Panel B: Sub-period } 2 \\
\text { (Jul. 97 to Jul. 05) }\end{array}$} \\
\hline DJIA & 1 & $0.65 * *$ & $0.92 * *$ & $0.26^{*}$ & $0.25^{*}$ & $0.25^{*}$ \\
\hline NASDAQ & $0.65 * *$ & 1 & $0.81 * *$ & $0.39 * *$ & $0.47 * *$ & $0.44 * *$ \\
\hline S\&P 500 & $0.92 * *$ & $0.81 * *$ & 1 & $0.28 * *$ & $0.28 * *$ & $0.27 * *$ \\
\hline \multicolumn{7}{|c|}{$\begin{array}{l}\text { ** Correlation is significant at the } 0.01 \text { level (2-tailed). } \\
\text { * Correlation is significant at the } 0.05 \text { level ( } 2 \text {-tailed). } \\
\text { Note: Results of parametric (Pearson correlations coefficients) and non-parametric (Spearman rank correlation coefficients) } \\
\text { statistics were generally identical. }\end{array}$} \\
\hline
\end{tabular}

The correlation coefficients between the U.S. stock indexes and the Indian stock indexes have clearly increased from the first to the second sub-period. This is consistent with prior studies, including the findings of Patel (2003). However, we believe that it is important to note the following point before drawing any conclusion that diversification benefits from investing in India have decreased: We document the fact that, even though the correlation coefficients between the U.S. and Indian indexes are higher in the second period, these correlations remain substantially lower than the correlations among the U.S. indexes. Also, Patel (2003) demonstrated that the Indian stock market (as well as the other South Asian markets) had comparatively lower correlations with the U.S. stock 
market than did the other emerging markets of Asia during the later time period in that study (i.e., July 1997 to December 2001). We conclude that, although the correlations between the U.S. and Indian stock markets increased in recent years, the Indian market continues to provide significant diversification benefits for U.S. investors.

\begin{tabular}{|c|c|c|}
\hline \multicolumn{3}{|c|}{ Table 4} \\
\hline \multicolumn{3}{|c|}{$\begin{array}{c}\text { Correlations Of Each U.S. Stock Index With The Average Of Other Two U.S. Indexes } \\
\text { And The Three Indian Indexes: Two Sub-Periods }\end{array}$} \\
\hline Index & Other Two U.S. Stock Indexes & Three Indian Stock Indexes \\
\hline \multicolumn{3}{|c|}{$\begin{array}{l}\text { Panel A: Sub-period } 1 \\
\text { (Jan. 91 to Jun. 97) }\end{array}$} \\
\hline DJIA & 0.80 & 0.01 \\
\hline NASDAQ & 0.71 & 0.06 \\
\hline S\&P 500 & 0.85 & -0.02 \\
\hline Average & 0.79 & 0.02 \\
\hline \multicolumn{3}{|c|}{$\begin{array}{l}\text { Panel B: Sub-period } 2 \\
\text { (Jul. } 97 \text { to Jul. 05) }\end{array}$} \\
\hline DJIA & 0.79 & 0.25 \\
\hline NASDAQ & 0.73 & 0.43 \\
\hline $\mathrm{S} \& \mathrm{P} 500$ & 0.87 & 0.28 \\
\hline Average & 0.80 & 0.32 \\
\hline
\end{tabular}

We can perhaps address this issue more succinctly by computing the correlation for each U.S. stock index with the average of the other two U.S. indexes, and comparing these results with the averages for the three Indian stock indexes over both sub-periods. The results of these comparisons are presented in Table 4.

The average correlation of a U.S. stock index with the average of the other two U.S. stock indexes has remained virtually unchanged from the first sub-period $(0.79)$ to the second sub-period $(0.80)$. On the other hand, as previously noted, the average correlation between the U.S. stock indexes with the average of the Indian stock indexes has increased substantially from the first sub-period $(0.02)$ to the second sub-period $(0.32)$. But, we would rather argue that we should compare the correlations by sub-periods. In the second sub-period, U.S. investors could have still reduced risk dramatically by diversifying in to the Indian stock market, as opposed to investing only domestically. The average correlation between the average of the U.S. and Indian stock indexes (0.32) is still considerably lower than the correlation among the U.S. stock indexes (0.80).

\section{VARIOUS SUB-PERIODS OF U.S. STOCK MARKET DECLINE}

It is clearly important to document how the foreign stock markets perform during periods when the U.S. stock market generates relatively lower returns. We find some very interesting results in Table 5. In Panel A, we divide the data based on our previous analysis and that of Patel (2003). The first sub-period, January 1991 to June 1997, is a period of relatively high returns in the both the U.S. stock market and the Indian market. During this period, a U.S. investor could have earned high positive returns by either investing domestically only or diversifying by allocating some funds to the Indian stock market. However, our objective is to determine whether a U.S. investor can continue to receive comparably high returns during periods of decline in the domestic market. Therefore, we are more interested in analyzing the performance of the Indian market during the second sub-period, July 1997 to July 2005. Recall that this sub-period is utilized by Patel (2003), and in Tables 3 and 4. We find that the Indian market generated substantially higher returns than did the U.S. market during this period (Table 5, sub-period 2). We conclude that the Indian stock market offers diversification benefits to U.S. investors during periods of decline in the domestic stock market. 


\begin{tabular}{|c|c|c|c|c|}
\hline \multicolumn{5}{|c|}{ Table 5} \\
\hline \multicolumn{5}{|c|}{$\begin{array}{l}\text { Average Monthly Returns Of U.S. And Indian Stock Market Indexes } \\
\text { Four Sub-Periods }\end{array}$} \\
\hline & \multicolumn{2}{|c|}{ Panel A } & \multicolumn{2}{|c|}{ Panel B } \\
\hline Index & $\begin{array}{c}\text { Sub-period } 1 \\
\text { Jan. } 91 \text { to Jun. } 97\end{array}$ & $\begin{array}{c}\text { Sub-period } 2 \\
\text { Jul. } 97 \text { to Jul. } 05\end{array}$ & $\begin{array}{c}\text { Sub-period } 3 \\
\text { Jan. } 91 \text { to Dec. } 99\end{array}$ & $\begin{array}{c}\text { Sub-period } 4 \\
\text { Jan. } 00 \text { to Jul. } 05\end{array}$ \\
\hline DJIA & 1.43 & 0.45 & 1.45 & -0.01 \\
\hline NASDAQ & 1.84 & 0.84 & 2.40 & -0.51 \\
\hline S\&P 500 & 1.32 & 0.46 & 1.46 & -0.16 \\
\hline BSE 30 & 1.43 & 0.71 & 1.10 & 0.91 \\
\hline BSE 100 & 1.18 & 1.02 & 1.12 & 1.04 \\
\hline BSE 200 & 1.18 & 1.09 & 1.13 & 1.13 \\
\hline
\end{tabular}

We realize that the U.S. market began a significant downturn in early 2000, and continued to decline almost continuously for about three years. We believe it is very important, and revealing, to compare the performance of the two markets during these tumultuous periods. We report these results in Panel B of Table 5. Sub-period 3 displays market performance during the period January 1991 to December 1999, and, in sub-period 4, we report performance for the period January 2000 to July 2005. The results are remarkable. The U.S. market produced very high returns during the nineties (sub-period 3 in Table 5) and negative returns during the period January 2000 to July 2005 (subperiod 4 in Table 5). In contrast, the Indian stock market had consistently high positive returns during the latter period (i.e., sub-period 4). It appears that U.S. investors can derive substantial benefits from investing in the Indian stock market during periods of domestic market decline. The Indian stock market appears to be a perfect destination for diversification and investment.

Next, we analyze whether returns for the recent sub-period January 2000 to July 2005 are significantly lower than during the January 1991 to December 1999 sub-period. For each of the six stock indexes, we utilize the following regression equation in order to make these comparisons:

Index return $=\alpha+\beta D_{1 t}$

where $D_{1 t}$ is a dummy variable equal to one for observations in the second sub-period (January 2000 to July 2005) and equal to zero otherwise. Therefore the $\beta$ coefficient represents the difference between mean monthly returns during the second sub-period and mean monthly returns over the rest of the sample. The intercept $(\alpha)$ measures mean monthly returns for the first sub-period. Then the $\beta$ coefficient is the magnitude of the difference between the second sub-period mean monthly return and the first sub-period mean monthly return. If the $\beta$ coefficient is negative and statistically significant, then it indicates that mean returns during the second sub-period are significantly less than mean returns for the first sub-period.

The results of these comparisons are reported in Table 6. We find very interesting results. All three U.S. indexes indicate significantly lower returns in recent years (second sub-period) than during the earlier years (first subperiod). On the other hand, the three Indian indexes do not generate significantly lower returns in recent years. It appears that U.S. investors could have obtained benefits, in terms of return and risk-reduction, by investing in the Indian market during the period of domestic stock market decline. Our results challenge the notion that international stock markets are integrating and, therefore, that investing internationally does not offer diversification benefits. In our study we find that the Indian stock market continues to offer important diversification benefits to U.S. investors.

We next investigate this important result in greater detail. The U.S. stock market generated negative returns over the period 2000 to July 2005; however, returns during 2003 were positive. In fact, in the U.S. market, returns were relatively high during 2003 . We replicate the previous analysis in order to focus further on the period January 2000 to July 2005, but we remove 2003 from the sub-period. 


\begin{tabular}{|c|c|c|c|c|c|}
\hline \multicolumn{6}{|c|}{ Table 6} \\
\hline \multicolumn{6}{|c|}{$\begin{array}{l}\text { Ordinary Least Squares Regressions Of The Two U.S. Sub-Periods } \\
\text { Index Return }=\alpha+\beta D_{1 \mathrm{t}}\end{array}$} \\
\hline Index & $\boldsymbol{\alpha}$ & $\boldsymbol{\beta}$ & F-Value & Significance & DF \\
\hline DJIA & $\begin{array}{c}1.45 * * * \\
(0.00)\end{array}$ & $\begin{array}{c}-1.46^{* *} \\
(0.02)\end{array}$ & 5.21 & 0.02 & $1 ; 173$ \\
\hline NASDAQ & $\begin{array}{c}2.40 * * * \\
(0.00)\end{array}$ & $\begin{array}{c}-2.91 * * * \\
(0.01)\end{array}$ & 6.71 & 0.01 & $1 ; 173$ \\
\hline S\&P 500 & $\begin{array}{l}1.46 * * * \\
(0.00)\end{array}$ & $\begin{array}{c}-1.62 * * * \\
(0.01)\end{array}$ & 6.70 & 0.01 & $1 ; 173$ \\
\hline BSE 30 & $\begin{array}{c}1.10 \\
(0.19)\end{array}$ & $\begin{array}{l}-0.19 \\
(0.89)\end{array}$ & 0.02 & 0.89 & $1 ; 173$ \\
\hline BSE 100 & $\begin{array}{c}1.12 \\
(0.21)\end{array}$ & $\begin{array}{l}-0.08 \\
(0.95)\end{array}$ & 0.00 & 0.95 & $1 ; 173$ \\
\hline BSE 200 & $\begin{array}{c}1.13 \\
(0.24)\end{array}$ & $\begin{array}{c}0.00 \\
(1.00)\end{array}$ & 0.00 & 1.00 & $1 ; 173$ \\
\hline $\begin{array}{r}* * * \text { Significant } \\
* * \text { Significant } \\
\text { *Significant } \\
\text { The first sub } \\
\text { The second } \\
\text { The } p \text {-value }\end{array}$ & $\begin{array}{l}\text { evel. } \\
\text { evel. } \\
\text { evel. } \\
\text { ludes } 199 \\
\text { is from Ja } \\
\text { atistic app }\end{array}$ & $\begin{array}{l}\text { ul. } 2005 \text {. } \\
\text { theses und }\end{array}$ & ients. & & \\
\hline
\end{tabular}

\begin{tabular}{|ccccc|}
\hline \multicolumn{5}{c|}{ Table 7 } \\
\hline \multicolumn{5}{|c|}{ Average Monthly Returns Of U.S. And Indian Stock Market Indexes: Two Sub-Periods } \\
\hline Index & Sub-period 1 & Observations & Sub-period 2 & Observations \\
\hline DJIA & 1.50 & 120 & -0.44 & 55 \\
NASDAQ & 2.51 & 120 & -1.38 & 55 \\
S\&P 500 & 1.51 & 120 & -0.64 & 55 \\
BSE 30 & 1.53 & 120 & -0.07 & 55 \\
BSE 100 & 1.61 & 120 & -0.05 & 55 \\
BSE 200 & 1.66 & 120 & -0.04 & 55 \\
\hline Note: The first sub-period includes 1991 to 1999 and 2003. The second sub-period is from Jan. 2000 to Jul. 2005 excluding the \\
year 2003.
\end{tabular}

Mean monthly returns for sub-period 1 in Table 7 include returns for 1991 to 1999, and for 2003. Mean monthly returns for sub-period 2 cover the period January 2000 to July 2005 with the exception that 2003 is excluded. For the first sub-period, the mean monthly returns for both the U.S. and Indian stock markets are relatively high. However, we are primarily concerned with sub-period 2. The U.S. stock market generated substantial negative returns during this period while, in contrast, the Indian stock market did not perform as poorly. We can further analyze these diversification benefits from the results presented in Table 8 .

In Table 8, we report results similar to those in Table 6. Regressions for the three U.S. indexes indicate a negative and statistically significant independent variable. This implies that the three U.S. indexes have significantly lower returns in the second sub-period than in the first. We do not find a statistically significant independent variable for the three Indian indexes, so that returns for the second-sub-period are not statistically significantly less than the first sub-period returns. 


\begin{tabular}{|c|c|c|c|c|c|}
\hline \multicolumn{6}{|c|}{ Table 8} \\
\hline \multicolumn{6}{|c|}{$\begin{array}{l}\text { Ordinary Least Squares Regressions Of The Two U.S. Sub-Periods } \\
\text { Index Return }=\alpha+\beta D_{1 \mathrm{t}}\end{array}$} \\
\hline Index & $\alpha$ & $\beta$ & F-Value & Significance & DF \\
\hline DJIA & $\begin{array}{c}1.50 * * * \\
(0.00)\end{array}$ & $\begin{array}{c}-1.94 * * * \\
(0.00)\end{array}$ & 8.53 & 0.00 & $1 ; 173$ \\
\hline NASDAQ & $\begin{array}{l}2.51 * * * \\
(0.00)\end{array}$ & $\begin{array}{l}-3.89 * * * \\
(0.00)\end{array}$ & 11.27 & 0.00 & $1 ; 173$ \\
\hline S\&P 500 & $\begin{array}{l}1.51 * * * \\
(0.00)\end{array}$ & $\begin{array}{c}-2.15^{* * *} \\
(0.01)\end{array}$ & 11.04 & 0.00 & $1 ; 173$ \\
\hline BSE 30 & $\begin{array}{l}1.53^{*} \\
(0.06)\end{array}$ & $\begin{array}{l}-1.60 \\
(0.26)\end{array}$ & 1.25 & 0.27 & $1 ; 173$ \\
\hline BSE 100 & $\begin{array}{l}1.61^{*} \\
(0.06)\end{array}$ & $\begin{array}{l}-1.66 \\
(0.27)\end{array}$ & 1.22 & 0.27 & $1 ; 173$ \\
\hline BSE 200 & $\begin{array}{l}1.66^{*} \\
(0.07)\end{array}$ & $\begin{array}{l}-1.70 \\
(0.29)\end{array}$ & 1.12 & 0.29 & $1 ; 173$ \\
\hline $\begin{array}{c}\text { *** Significant } \\
\text { **Significant } \\
\text { *Significant } \\
\text { The first sut } \\
\text { The second } \\
\text { The } p \text {-value }\end{array}$ & $\begin{array}{l}\text { level. } \\
\text { level. } \\
\text { level. } \\
\text { cludes 199 } \\
\text { is from Jc } \\
\text { tatistic ap }\end{array}$ & $\begin{array}{l}\text { nd } 2003 \text {. } \\
\text { Jul. } 2005 \text { ex } \\
\text { atheses und }\end{array}$ & $\begin{array}{l} \\
\text { year } 2003 . \\
\text { cients. }\end{array}$ & & \\
\hline
\end{tabular}

\section{SUMMARY AND CONCLUSIONS}

We re-examined and extended Patel's (2003) findings. In this study, we used different stock market indexes, extended the data and focused our analysis on a comparison of the U.S. and the Indian stock markets. More specifically, we examined three major U.S. stock market indexes, the DJIA, the NASDAQ and the S\&P 500, and three major Indian stock market indexes, the BSE 30, the BSE 100 and the BSE 200, over the period January 1991 to July 2005. We find some very interesting results. First, the Indian stock market generated high returns, comparable to those of the U.S. stock market, for the entire period of the study. This period includes the 1990's when the U.S. stock market generated very high returns. Second, we find that the Indian stock market continues to offer diversification benefits to U.S. investors during the recent years of decline in the U.S. stock market. Our results were robust when we examined this conclusion using different sub-periods from the period of decline.

We believe that the Indian economy is expanding rapidly and Indian policy makers are encouraging foreign investment in India. U.S. investors should consider investing in the Indian stock market for diversification purposes and in order to enhance investment returns, particularly during periods of domestic stock market declines. More research should be done on the Indian stock market and its overall economy in order to improve our understanding of investment opportunities in India.

\section{ACKNOWLEDGEMENT}

I would like to thank R. Bruce Swensen for helpful comments and suggestions.

\section{REFERENCES}

1. Bala Arshanapalli and Mukun S. Kulkarni, Interrelationship between Indian and US Stock Markets, Journal of Management Research, Volume 1, Number 3, May-August 2001, pp. 141-148.

2. Bombay Stock Exchange Website, www.bseindia.com

3. Christopher B. Barry, John W. Peavy III, and Mauricio Rodriguez, Performance Characteristics of Emerging Capital Markets, Financial Analysts Journal, January/February 1998, pp. 72-80.

4. Arjun Chatrath, Sanjay Ramchander, and Frank Song, Benefits from Portfolio Diversification into the Indian Equity Market, American Business Review, January 1996, pp. 1-10. 
5. John Echeverri-Gent, Financial Globalization and India's Equity Market Reforms, India Review, Volume 3, Number 4, October 2004, pp. 306-332.

6. Federal Reserve Website, www.research.stlouisfed.org

7. Jayen B. Patel, Inter-Temporal Relationship Between the U.S. stock market and the Emerging Markets of Asia, Journal of Business and Economics Research, Volume 1, Number 10, October 2003, pp. 1-6.

8. World Bank Website, www.worldbank.org

9. Yahoo Website, www.finance.yahoo.com

\section{NOTES}

